friction. Foremen who were unfeeling and arbitrary in handling matters unimportant in themselves, had caused many valuable employes to leave the industry, despite the fact that their earnings were very high and that their work was very interesting.

It has been well worth while also for the industry to have maintained through its employment department a point of contact with the employes that has resulted in their feeling free to express themselves with reference to the adjustments that they thought should be made in their work or in their wages, whenever a foreman seemed to them to be insensible to their deserts.

It is because the employment department has been in a position to render such effective coöperation to heads of departments and to extend such encouragement to those employes who may have found themselves temporarily out of harmony with their work environment, that its work in this business has been so well worth while.

\title{
THE EMPLOYMENT WORK OF THE CURTIS PUBLISHING COMPANY
}

\author{
By Robert C. Clothier,
}

Employment Manager, The Curtis Publishing Company.

The raising of the standard of efficiency of the working force, individually and as a whole, in order that the purchasing power of the wage-dollar may be increased-this, as we interpret it, is the broad function of the employment department. It is not my intention to give you a finished speech tonight, for two reasons: first, because of a certain constitutional inability to do so; and second, because, although we feel that we are making progress in our efforts at human engineering, yet we have a long road to go before we even approach the end; so my paper tonight will be devoted merely to telling you about what we have succeeded in doing and in some measure what our plans are for the future.

The phrase "employment department" would be a misnomer if

${ }^{1}$ Paper read before Philadelphia Association for the Diseussion of Employment Problems, April, 1916. 
it were allowed to convey the idea of a department maintained merely to keep in touch with the labor market and to engage employes. Its function is infinitely broader. Summed up in one sentence, the employment department is the department whose duty it is to develop the efficiency of the workers, directly or indirectly, and to bring about a condition in which the individual employe will render as nearly as possible 100 per cent to his employer. The word "employ," therefore, should signify the care and development of the employes rather than the mere act of engaging workers and placing them on the payroll.

Personal efficiency is a composite article. It is composed of various proportions of brains, health, instruction, loyalty, enthusiasm, ambition, ability to coöperate, personality and character. If in each of our employes, we can develop these traits to the maximum, our product will be a worker who will deliver for the wage paid him far greater service than the worker who does not possess these qualities, - and to that more valuable worker we can, consequently, pay a higher wage.

At the Curtis Publishing Company we have felt that this purpose can best be served through a centralized employment department, under a manager reporting directly to the general manager of the company - a department composed of four divisions, as follows: first, the employment division, which assumes the task of selecting and engaging the help; second, the medical division, whose function, of course, is to see to the physical health of the employes; third, the instruction division, through which the employes are given the opportunity to increase their special ability and training; fourth, the welfare division, whose purpose is to create a favorable mental background for the workers. Let us consider these four divisions in order.

\section{Employment Division}

It is the duty of the manager of the employment division to keep in touch with the sources of labor supply and engage workers best qualified to fill the vacancies occurring in the organization. These vacancies are reported to it on labor requisitions received from the executives of the operating departments. When a mechanical engineer constructs a machine, he naturally exercises the greatest care as to the quality of the material he puts into it. Similarly, when a 
human engineer is constantly at work building up an efficient working force, he must use the best care and discrimination in choosing the units which are to comprise it. Subsequent training is, of course, indispensable and frequently is instrumental in transforming unpromising employes into efficient workers; but the value of the training is greatly increased when it is applied to responsible materialand the result is much better.

The most fruitful source of supply is, in our experience, the file in our office in which are classified by kinds of work the application blanks filled out by individuals who have called seeking employment. Quite naturally, for every position that is open we have several applicants. Only one can be selected for the particular vacancy, but among the others are invariably several who are well qualified for consideration when other vacancies occur.

Another source of supply, if it may be called that, is that represented by our payroll. Whenever a position of any importance is to be filled, we go through our own organization first to see if there are persons we can promote to that position, rather than ignoring the good material within our organization and seeking first at the outside sources of supply.

Splendid material for stenographic and clerical work can usually be obtained from the high schools, the principals of which are naturally interested in placing their graduates. We have found it advantageous to establish a relationship of personal friendliness with the principals of several schools of this class.

Similar material of a clerical nature can often be obtained from the various typewriting agencies who, in a similar way, are interested in placing their clients.

There is, of course, a constant influx of applicants of a miscellaneous nature seeking employment with us. Among such applicants will be found hopeless derelicts, hard-luck victims, good manual laborers, good clerical help and trained college graduates who might prove valuable in executive positions. We find it well to study this material carefully. Much of it is worthless-some of it is excellent.

Naturally, the several employment bureaus of the city are always at our service, but owning to the nature of their clientele, it is inevitable that much undesirable material should pass through their doors. Too many bureaus of this kind operate in a mechanical 
way, without giving the vocational guidance to which applicants are entitled. Too frequently they feel their duty is done when they give an applicant a letter of introduction to an employer-regardless of whether or not he is particularly equipped for the employer's service or whether he is accepted. Progress is being made, however, toward a better and more intelligent service on the part of these bureaus.

And, of course, a vast quantity of material is available through the classified advertising columns of the newspapers. Advertisements of this kind naturally bring a certain proportion of applicants who are hopelessly unfit, but these can be rapidly eliminated and desirable applicants retained for more complete analysis and examination. Except where immediate action is needed, the blind advertisement is more satisfactory than the advertisement which mentions the employer's name. Blind advertisements automatically eliminate much of the hopeless material and enable the manager of the employment division to exercise preliminary judgment by analyzing the letters received from the applicants.

Applicants for positions in the Curtis Publishing Company are shown into an anteroom, where those who are obviously undesirable are weeded out. Those who deserve further consideration are requested to fill out application blanks which, when complete, show their age, their previous business experience, the names of their previous employers, the length of their service and their reasons for leaving those employers, their previous salary and the salary expected, and the names of references. Each of these blanks is delivered to the manager of the employment division, who thus has a chance to analyze each applicant's previous experience before the applicant himself is shown into the manager's inner office. Then comes the interview.

Doubtless each employment manager has his own particular system of sizing up applicants. We feel there is much to be gained from Doctor Katherine Blackford's teachings, although we are not prepared to accept them simon pure yet. Psychological tests in the selection of salesmen, as they are carried on by Professor Walter Dill Scott at the Northwestern University, seem to possess much that is of value in the selection and promotion of salesmen; such concerns as Hart, Schaffner and Marx, of Chicago, we believe, rely almost entirely upon Professor Scott. We do not employ his methods principally because we have practically no occasion to engage sales- 
men of this character. We feel there is much to be gained from phrenological examinations. With the most of us, however, the phrenological analysis of employes is still a science in its infancy.

Yet, most of us judge unconsciously by fundamental phrenological standards. A firm, steady eye indicates honesty and reliability and a shifty eye indicates shiftiness of character. With most of us, however, the color of the eye as yet remains of no significance. We judge by the set of the chin, the shape of the mouth, the courteous vigor of the hand-grip, the individual's address and bearing.

We judge, too, by the individual's clothes, for as a general proposition, conservation in clothes suggests a desirable mental equivalent, and shabbiness or carelessness in personal appearance indicates a certain mental carelessness that would be a liability in most positions.

For certain clerical positions such as those of stenographer, typist or auditor, the applicant is also required to undergo a test and to measure up to certain standards before he or she is referred to the executive in the operating department.

Immediately after the interview, or during it, the manager of the employment division fills out one of our analysis cards with which it is possible to mentally reconstruct the applicant at any future time, in order to consider him for any later vacancy, if he is not employed immediately. These analysis cards contain eight divisions, as follows:

Personality

Build

English

Type of Mind $\left\{\begin{array}{l}\text { Executive } \\ \text { Detail } \\ \text { Promotive } \\ \text { Accounting } \\ \text { Analytical }\end{array}\right.$

Appearance

Mentality $\left\{\begin{array}{l}\text { Super alert } \\ \text { Alert } \\ \text { Average } \\ \text { Slow } \\ \text { Dull }\end{array}\right.$

Initiative

Remarks

These phrases explain themselves, with the exception, possibly, of "super alert." This home-made phrase is intended to suggest 
that type of mind which is too active-almost effervescent; a type of mind which is seldom accompanied by the stability and saneness which are requisites in most positions.

Let us assume that a certain applicant has called at our employment office, has filled out an application blank, has been interviewed by the manager of our employment division and has passed satisfactorily. The applicant is then conducted to the executive of the operating department for whom he has been procured, and is interviewed by that executive, whose decision is final. If the applicant similarly satifies the operating executive, he is then sent back to the employment division and examined by the physician in our medical division, which is adjacent to the employment division. If our physician gives him a clean bill of health, the employe is then given the glad hand in the employment division, is told when and where to report, is given final instructions, and is made to feel as much at home as possible. He is also presented with a copy of our Book of Rules, which shortly is to be imprinted with the employe's name, as is now done at the employment department of the Dennison Manufacturing Company; Mr. Dennison explains the value of the printed name in the fact that the employe is certain to slip the book in his pocket and carry it home to read and that the value of the book to the company is enhanced tenfold as a result.

Letters of inquiry are then sent to the persons named as references by the applicant. The value of these references is moral rather than practical, as few employers will voluntarily stand in the way of an ex-employe of theirs securing employment elsewhere. For this reason, most replies are favorable in nature, and a favorable reply is not, therefore, of any significance. If, on the other hand, the responses are uniformly derogatory to the applicant, it suggests to the employment manager that perhaps a further investigation of the individual case is justified.

If the applicant should be rejected by the executive in the operating department, he is similarly sent back to the employment division, where he is either placed elsewhere in the organization or told that his application will be considered should any other vacancies arise for which he is qualified. Occasionally the judgment of the manager of the employment division and the operating executive will differ in this way; yet the employment department never makes an issue of such a case or endeavors to force an employe 
upon an unwilling executive. Such an issue would not only be bound to arouse antagonism on the part of the operating executive, which in turn would be fatal to harmonious and efficient work on the part of the employment department, but it would also fail of its purpose, inasmuch as whether or not the operating executive has the legislative activity to reject an applicant recommended by the employment department, he at least has the ability to make things so unpleasant for the new employe that he would willingly resign. This touches closely the question of coöperation between the employment department and the operating departments, regarding which I shall speak in a few minutes.

I have said that the application blanks of persons who are not placed in our organization are filed in a classified file. The classifications of this file are as follows:

Boys-under sixteen

Boys-over sixteen

High grade-male

Correspondents-female

Clerks-male

Clerks-female

Bindery-male

Bindery-female

Compositors

Electricians

Fly boys

Laborers

Pressmen

Pressmen's helpers

Shippers

Truck drivers

Phonograph operators and typists

Stenographers

Telephone operators

Undesirable

So much for the engaging of help. This, however, is not the complete function of the employment division. The employment division similarly acts as a clearing-house of labor between department and department and makes impossible a condition in which one department may be laying off help while another department of the company is engaging help of the same character. It is obligatory upon the employment division also to keep as accurate a report as possible of the performance of employes and to transfer those who are misplaced to other positions for which they are better fitted by 
temperament. At a recent meeting, Mr. Willits read Mr. Boyd Fisher's paper which was presented to the Employment Managers' Conference, at Minneapolis. He showed that from October, 1912 to October, 1913, the Ford Motor Company hired 54,000 men to keep an average working force of 13,000 - a labor turnover of over 400 per cent. The following year the Ford Company hired only 3,000 men to maintain an average of 23,000 ; this is a turnover of 23 per cent. At the present time the Ford turnover is lower still. When I was there recently, I was told by officials that only three men had been discharged from the Ford plant during seven months. Their total payroll is now about 24,000 . This tremendous reduction was due principally to the inauguration of the Ford profit-sharing scheme, but also in large measure to the policy adopted under Mr. Ford's direction that no man should be discharged from the company as long as it was possible to use him in any other capacity whatever. Sometimes men are shifted from job to job six or eight times and finally end up by swinging a sledge hammer or sweeping the floor-but they are retained on the payroll.

Mr. Ford incidentally has solved to some degree the problem of round pegs in square holes, and of course that is the work of every employment department-to fit the square pegs into the square holes and the round pegs into the round holes-to place each employe where he fits most perfectly. An employe who works at his job because he is fitted for it, because he enjoys it, and therefore, puts enthusiasm into his work, is worth far more to his employer than the worker who works indifferently at his job only because he is paid for it and who quits as on principle immediately on the stroke of the bell.

\section{Medical Division}

I have spoken of the medical division inasmuch as its work dovetails somewhat with the work of the employment division. Our men's hospital is situated next to the employment division. It consists of a waiting room, an outer office, where bandages are applied and minor injuries treated by the orderlies, and the inner office, where the doctor holds his examinations. Here our physician is in attendance every afternoon. An orderly is in attendance both day and night. Our women's hospital is geographically adjacent to our welfare division, which is under a woman manager; this arrangement is, therefore, highly desirable. Two nurses are constantly in attendance at the women's hospital during the day. 
The nature of the examination of new employes is as follows: eye-sight, hearing, throat, heart and lungs. The applicant is also examined closely to make sure he has no tubercular tendency. In addition, our doctor sees to it that the individual possesses the necessary physical strength and endurance for the particular work he is to assume, and of course, the new employe must be free from any impairment which might be communicated to his fellow workers.

At the present time we do not examine our employes periodically, although this is a development which may come in the future. The International Harvester Company and other similar concerns are sincere believers in the periodical examination as a preventive means of keeping their employes in good health. I have known of a number of cases in which periodical examinations of this kind would have saved a world of trouble to the employe and considerable expense to the company.

Employes who have been absent owing to illness are required to consult the company physician before returning to work. There is a natural impatience on the part of the average worker to get back on the job, and this frequently leads him to return before he has established that margin of health that makes for continuous service thereafter.

\section{Instruction}

Three good-sized rooms, well-lighted, comprise the quarters of our instruction division. Instruction is the process of training a new employe capable of delivering perhaps 10 per cent service into a trained worker capable of delivering 90 per cent service or better. Methods of training differ with different concerns. Some concerns, owing to the nature of their work, find it best to maintain schools, under salaried teachers, for this purpose. Other concerns have their instruction work done departmentally by persons designated to that task or even by foremen and fellow employes. Where the instruction work is done in this way, the employment department should be an interested party. It should either exercise direct control or a strong advisory influence.

Most of our work at the present time is done departmentally. The classes conducted under our instruction division are purely voluntary. A salaried teacher is in attendance; she has her regular schedule of lessons. Classes in Stenography and Touch Typewriting are very popular. Also, under the auspices of the 
Curtis Country Club, which I shall describe later, classes are held in English, Commercial Geography, Business Mathematics, Penmanship and Spelling. Inasmuch as these classes are voluntary, it is particularly gratifying that their popularity is increasing all the time.

About 80 of the boys in our employ are under 16 years of age and are, therefore, subject to the new child labor law, which requires them to attend school eight hours a week. We have coöperated with the school authorities in Philadelphia by placing one of the rooms in the instruction division at their disposal. Here a teacher furnished by the School Board holds classes three days a week.

Our Apprentice School for compositors is rather a unique organization, conducted under the direction of the manager of our composition division, where the type is set for the Curtis publications. The school is maintained under competent instructors and here, through a course of five years, boys are developed from raw beginners into finished compositors. It is here we recruit our stock of compositors when they are needed. The compensation paid to the boys during their five-year course increases every six months.

\section{Welfare}

Now for the fourth division of the employment division, namely, the welfare division. The work of this division has direct reference to the state of mind of the employe. This division of the work is founded on the certainty that an employe who is happy and satisfied and free from anxiety and who works under favorable physical conditions will do better work and more of it than an employe who is dissatisfied, fearful of the future, and who does his work in an unfavorable physical environment. For want of a better name, this division of the work is called "welfare work," a phrase which has fallen into some disrepute in some quarters because those in charge of welfare in certain establishments have let their hearts lead them astray and because, through lack of tact and judgment, welfare work in some quarters has been permitted to be interpreted by the employes themselves as touching on altruism and charity.

Welfare work is not altruism; it is not charity. Industry is coming to regard personnel as one of the big factors to be considered 
in every undertaking, and if this is so, then the work of the welfare department is an economic necessity. But this work must be conducted along economic lines, as every other department is conducted; every dollar spent on it must yield 100 cents in return. It must be thoroughly leavened with good, hard common-sense.

It is the duty of the welfare division to go after the fundamental things first. The question of wages and hours of labor are, of course, such broad subjects that all the administrative officials of the company collaborate on them. The welfare division, however, gives constant attention to matters of almost equal significance, the conditions under which the employes work-light, air, safety devices, sanitary arrangements, elevator service. It is not reasonable to expect an employe to reach his or her place of work in the establishment in the right frame of mind to tackle the day's work with willingness, if he has to pass through the gamut of dark, congested coat rooms and either climb several flights of stairs or wait his turn to get into an elevator together with a crowd of other workers, all as vexed as he. It is not reasonable to expect him to deliver as much service for the wages, if the light is dim or the air is vitiated or the safety devices inadequate. To bring the individual employe to the frame of mind where he is able to deliver efficient services, it is obvious that the employer, through the welfare division, should arrange for those physical surroundings which will breed self-respect, cheerfulness and confidence.

The architect who planned the Curtis building allowed for large windows, so that our employes secure a maximum amount of daylight. Throughout our clerical departments, indirect lighting is used, thus avoiding the harmful glare of incandescent bulbs. The air throughout our building is warmed as it is drawn through ventilators on the roof and is changed every ten minutes. The small number of industrial accidents in our manufacturing plant suggests, to a certain extent at least, that we have satisfactorily safeguarded our machinery. Our locker rooms, toilets and washrooms are, we believe, as sanitary as scientific plumbing can make them.

Restaurants are maintained, where our employes can secure their meals at minimum rates without going outside. Restaurants of this kind require no attorney to argue their worth, especially as they are largely self-supporting. Good food makes for good health, especially when served under agreeable conditions, and the lunch 
hour is the time when the employes meet socially and esprit de corps is developed. Our restaurants cost us 17 cents per meal served. The price per meal paid by the employes approximates 13 cents. Twenty-one hundred persons are served daily, about 70 per cent of our force.

We have two rest rooms, which are placed at the disposal of the 1,100 women who are in our employ. These rooms are comfortably furnished with wicker furniture; the originals of paintings which have appeared in the Curtis publications hang on the walls. We have endeavored to create as far as possible an atmosphere of quiet and restfulness. These rooms are open to the employes during lunch hour.

In addition, we have a recreation room, where those who wish to talk and dance and engage in more active pursuits are permitted to make as much noise as they wish.

Our welfare library comprises 6,000 books, which are much in demand among our employes, men and women alike. We distribute about 100 books a day on an average. We offer unostentatiously guidance in reading-frequently we have been able by tactful suggestion to direct employes from "The Poisoned Gumdrop" type of book to something more worth while.

Two rooms are placed at the disposal of our men employes to use during the lunch hour. One is a recreation room where conversation and game playing are encouraged. The other is our men's reading room where quiet is maintained. Smoking is of course permitted in both. We find these rooms justify their expense many times over by keeping the men in the building during noon hour and keeping them away from the corner poolroom and saloon.

As a further means of creating this favorable mental background of which I have spoken, there is maintained, under the direction of our welfare division, a savings fund, in which employes may place sums varying from 25 cents to $\$ 5.00$ a week. This fund ordinarily pays 9 per cent to 10 per cent interest. At the end of the year the employes may withdraw their deposits and re-deposit them in a permanent fund, which pays 5 per cent a year. We feel that there is nothing like money in the bank to create a feeling of selfrespect. 
In addition, we have a Mutual Benefit Association, through which, for a nominal payment, the employes derive sick benefits when they are absent owing to illness.

Under the welfare division a staff of several women is maintained to call upon the employes who are absent on account of sickness to assist them in any reasonable way and to express the company's interest in them. This work naturally requires tact and judgment, for any careless phrase interpreted by the sick employe as savoring of charity would be resented.

Here I would like to say a few words in reference to the Curtis Country Club, the central social organization of our employes. To become a member of the Curtis Country Club, a person must be an employe of the Curtis Publishing Company and must pay his dues which, incidentally, are merely nominal. The company has absolutely no hand in its management. The club is self-conducted and, to a large extent, self-maintaining. For the past few years it has occupied an old farm house near Swarthmore, but recently the company purchased a tract of land at Lawndale, just north of the city, and is now building a well-equipped clubhouse. Athletic fields and tennis courts are being laid out, a swimming pool will be part of the equipment when it is finished, traps will be installed for those who wish to wing the elusive clay pigeon. This equipment will naturally belong to the Curtis Publishing Company, which, as landlord, will lease it to the Curtis Country Club as tenant. You will notice from the relation between the Curtis Publishing Company and the Curtis Country Club that the company wishes to avoid all semblance of paternalism. This has, in fact, been our policy throughout. As far as we can see it, paternalism is injurious on every count. It tends to spoil those employes who are looking for something for nothing and offends the self-respect of others of a more independent temperament. In all these extraneous activities and, as far as possible, in the workings of the departments themselves, we endeavor to give the employe a chance to govern himself rather than to dictate what he shall or shall not do.

The Country Club is operated largely through committees, such as the sports committee, the house and grounds committee, the educational committee. Under the latter, the voluntary classes are held in the instruction division, and periodically, motion pictures 
of an educational nature are displayed in the Curtis Auditorium, which the company gladly volunteers for the purpose. During the winter time, too, dances are frequently held in the Auditorium or in the Recreation Room, and during the spring and summer months, the employes are to be found in large numbers at the Country Club in the late afternoons and on Saturdays and Sundays.

Outside the city, too, near Swarthmore, the welfare division maintains a camp for its boys. Here the boys sleep in tents on army cots and eat at a central lodge where a college man counsellor and a colored cook hold forth. A good crowd of boys spend every Saturday and Sunday at camp; many stay there during their vacations. A nominal charge is made which, while it offsets only in very small part the cost of maintenance, yet give the boys the feeling that "They are paying their own way."

Marshall Field and Company of Chicago, has succeeded in developing to a large extent among their employes the feeling that some body is interested in their individual success. At best, business is a cold proposition, especially for the clerk or workman drawing minimum pay, who is regarded too often as a piece of machinery only. It is too frequently forgotten that he is a human being, too, with human problems of his own. We have taken a leaf from the experience of Marshall Field and are now trying to develop the same feeling on the part of our employes. Within a few weeks after a new employe is placed on the payroll, therefore, he receives a personal invitation to call at the office of the welfare manager, who talks over with him or her, as the case may be, the employe's progress and advancement. It is, without question, encouraging to the individual to realize that he is not lost in the shuffle but that somebody has his eye on him.

As a matter of fact, the welfare manager, and indeed all the managers in the employment department, must be willing and ready to act as confidant to any employe who comes to discuss his problems. One of the defects in most business organizations of today is that while it is easy enough for intelligence to be transmitted from the management to the employes, it is practically impossible for the employes to present their sincere opinions to the management. Regardless of how unfounded the feeling may be, most employes believe that by voicing complaints or criticisms of any kind, they jeopardize their standing in the company and even risk their 
positions; yet without just this information, it is impossible for the management intelligently to mould working conditions in such a way that they will be conducive to enthusiasm and efficiency on the part of the workers. This, as we see it, is one of the principal functions of the employment department-to act as the channel of communication between the employe and the employer and to act as spokesman for the employe in the councils of the management. All employes should be invited to feel free to come to the welfare division at any time for an informal talk.

Some concerns take positive steps to encourage the making of suggestions on the part of the employes relative to bettering the working conditions. The National Cash Register Company, for instance, distributes in prizes $\$ 1,500$ each year, and Mr. Illman, their welfare manager, told me recently that it was money very well spent. As yet we have not taken any steps in this direction; it is on the lists, however, for future consideration.

I have outlined now the functions of four divisions of our employment department: namely, the employment, the medical, the instruction and the welfare. This is the machinery with which we have to work and naturally the question might be asked, how do we know when it is working well? I might suggest in answer that perhaps the truest indication of the efficiency of an employment department is, in the long run, the labor turnover figures.

We men who are here tonight may have different ways of computing labor turnover, so for consistency's sake, I will say that we interpret it as the amount of change that takes place in the working force. 'Worked out in figures, it represents the percentage of "hiring and firing" in a year to the average total payroll. A high labor turnover represents not only a large sum total of human suffering but a tremendous money loss to the employer. You will remember that Mr. Magnus Alexander, in speaking to this Association, said that the managers of various establishments which he had investigated estimated the cost of hiring and breaking in an employe at from $\$ 50$ to $\$ 200$ each. With these figures in mind, let's estimate, each to ourselves, what the cost has been to us through the number of discharges that have taken place in our several organizations owing to purely superficial reasons, such as a minor disagreement between a foreman and a worker or because someone interpreted as 
insubordinate a certain independence of expression which, properly directed, might have been a direct asset to the company.

We are beginning to see the light these days. The time is passing when managers believed in the mailed-fist type of discipline and the periodic firing of employes for the avowed purpose of inspiring the others with proper fear and respect. Instead, the most callous of us are beginning to realize that fear-controlled employes deliver only a fraction of the service rendered by the employes who are inspired by enthusiasm. As Mr. Willits quoted at our last meeting, "Any mutt can fire a man," but it takes real brains to analyze that man, place him where he belongs in the organization and capitalize his abilities as an efficient worker.

The labor turnover figures are then, as I have said, a fairly accurate measure of the efficiency of the employment department, and the employment department should take steps to reduce the turnover by every means at its command. What are the methods by which this can be done? First, of course, by intelligent selection. Second, by intelligent instruction work, so that the employe will not fail to make good through inadequate preparation for his tasks. Third, by creating in him a satisfied spirit, as far as welfare work, properly conducted, can do it. Fourth, by stimulating hope of advancement throughout the organization by adopting the policy of filling vacancies from within and giving the employe the opportunity to advance to positions of greater responsibility and compensation as fast as his ability warrants it. Fifth, by reducing as far as possible the number of arbitrary and unjustified dismissals. Sixth, by working with the administrative officials of the company to standardize the rate of production, if possible, either by manufacturing for stock instead of on order or by rearranging the schedule of production in such a way that the average output and, consequently, the working force will remain uniform. Seventh, by acting as a clearing house for labor between the various operating departments, in order to prevent one department from discharging help because of slack work while another is adding to its force by placing elsewhere in the organization employes who fail to make good where first assigned. Eighth, by the preparation of comparative statements showing the labor turnover by departments and by seeing to it that the departmental executives fully understand the cost of a high turnover; as capable managers they will 
naturally be anxious to reduce it. Such comparative statements are not only of value in jacking up the delinquent managers but in revealing to the employment department what parts of the company first require investigation and remedy.

Now for another function of the employment department: the strictly military form of organization is coming under the microscope and flaws are being discovered. Industry is coming to see that the executive who says "Do this" to his subordinates, and fails to help them, is not as valuable as the executive who regards it as his first duty to aid his workmen. The executive is not to command but to assist. The workers are the men who turn out the goods, and the business organization which is permeated with this spirit of cooperation between boss and worker is certain to possess a higher degree of efficiency than the business which is built along the oldtime military lines.

The employment department should aid and abet the development of this spirit, both through the personal efforts of its manager and his assistants, in giving the operating foremen a broader point of view and by the adoption of departmental policies which work to that end.

This touches closely the question of discharge. The fear of peremptory discharge is often the cause of lessened efficiency on the part of the employe. Fear and enthusiasm cannot reside side by side in the same individual's mind. The theory of the old military system-that of discharging a number of workers occasionally, for the purpose of scaring the others into good behavior - fails entirely to take into consideration the fact that such a policy, while doubtless compelling sullen obedience on the part of the individual, lowers the efficiency of the force as a whole-and, of course, increases directly labor turnover.

Ultimate discharge from our company must take place through the employment department. Individual executives may discharge employes from their departments, but if vacancies exist elsewhere, the employment department may place these employes in other departments. Consequently, we interview the employes who are released. We find that employes who are leaving the company's service are more willing to speak their minds freely than those who, still being employed, feel that they endanger their interests by so doing. In this way it is frequently possible to obtain information 
from the employe's point of view which is of real value in enabling the employment department and the proper departmental executive to remedy conditions which tend to impair the efficiency of the workers. It is quite natural that a comparative record of discharges by reasons and by departments should have the effect of reducing the number of employes who are discharged for superficial reasons.

In closing, let me point out that by the very nature of its field, the employment department must be a service department. It is not an operating department, but it should work hand-in-glove with the operating departments, helping them in a genuinely sincere way to increase their own efficiency, through increasing the efficiency of their employes. It should not seek credit for what it does, only results-on which in the end it must stand or fall. Many of its achievements for the improvement of the working force must be accomplished indirectly, by counsel and advice, and the credit oftentimes must go elsewhere-but that, of course, is of minor significance. If by its activity, either direct or indirect, there results permanent economic advantage to the company through the improvement of its human relations, the employment department will take its place in the organization as one of the productive departments.

\title{
THE WORK PROGRAM OF THE EMPLOYMENT MANA- GERS' ASSOCIATION OF BOSTON
}

\author{
By Ralph G. Wells,
}

Secretary, Boston Employment Managers' Association.

Introductory Note. Credit for the formation of the Employment Managers' Association of Boston should be given to the Vocation Bureau of Boston. The Director, Meyer Bloomfield, had for some time believed that it was desirable to bring employment managers together to discuss the problems of their work. In 1910 an extensive investigation was inaugurated among the larger mercantile and industrial establishments in regard to vocations open to boys and young men. In this connection the Vocation Bureau came in contact with many employment managers, and found them in favor of conferences on employment subjects. Responding to this sentiment such conferences were arranged by the Bureau resulting eventually in the formation of the Association.

The Employment Managers' Association, like other similar organizations, was formed several years ago by the Vocation 